\title{
Botulismo tipo C em ganso ocorrido em Minas Gerais, Brasil
}

\author{
Type C botulism in a goose at Minas Gerais, Brazil
}

\author{
Francisco Carlos Faria Lobato ${ }^{\mathrm{I}^{*}}$ Felipe Masiero Salvarani ${ }^{\mathrm{I}}$ Rodrigo Otávio Silveira Silva ${ }^{\mathrm{I}}$ \\ Nelson Rodrigo Souza Martins ${ }^{\mathrm{I}}$ Andréa Márcia de Souza ${ }^{\mathrm{I}}$ Maurício Baltazar de Carvalho Filho ${ }^{\mathrm{II}}$ \\ Ricardo Aurélio Pinto Nascimento ${ }^{\text {II }}$ Ronnie Antunes de Assis ${ }^{\text {II }}$
}

\begin{abstract}
RESUMO
Botulismo é uma intoxicação causada pela ingestão das toxinas produzidas pelo Clostridium botulinum, que acomete mamíferos e aves, caracterizando-se por um quadro de paralisia flácida. Neste trabalho, é descrito um caso de botulismo em ganso, ocorrido no município de Santa Luzia, região metropolitana de Belo Horizonte, no Estado de Minas Gerais. Ao exame clínico, o animal apresentava-se com um quadro de paralisia flácida dos músculos do pescoço, das pernas e asas, além de apresentar ainda desprendimento de penas. A necropsia não revelou lesões significativas. Foi colhido o soro do animal e submetido ao teste de soroneutralização em camundongo, que identificou a toxina de C. botulinum tipo $C$.

Palavras-chave: botulismo tipo C, Clostridium botulinum, ganso, aves.
\end{abstract}

-NOTA-

\section{ABSTRACT}

Botulism is an intoxication caused by the ingestion of toxins produced by Clostridium botulinum, that affects mammals and birds, characterized by a flaceid paralysis. This report describes a case of botulism in a goose in Santa Luzia, Minas Gerais State, Brazil. Clinical examinations showed dropping feathers and flaccid paralysis involving the muscles of the wings, legs and neck. Post-mortem examination showed no significant gross or macroscopic lesions $C$. botulinum type $\boldsymbol{C}$ toxin was demonstrated in the serum of the affected animal through serum neutralization test in mice.

Key words: botulism type $C$, Clostridium botulinum, goose, waterfowl.
Botulismo é uma doença paralisante que acomete aves e mamíferos. É causada pela ingestão de neurotoxina letal produzida pelo Clostridium botulinum, bactéria anaeróbia estrita, habitante normal do solo e que pode esporular em condições adversas. Existem sete tipos de $\boldsymbol{C}$. botulinum, classificados de A até $\mathrm{G}$, sendo o tipo $\mathrm{C}$ o principal responsável por casos de botulismo em aves (WOBESER, 1997).

O agente é ubiquitário, podendo se desenvolver em vários tipos de substratos, desde que haja um ambiente favorável, associado a condições de anaerobiose que permitam sua multiplicação, tais como cadáveres, alimentos, poças e lagoas com água estagnada. Comumente as aves se intoxicam ao ingerirem larvas de moscas presentes nos cadáveres em decomposição (TAKEDA et al., 2006)

As toxinas produzidas pelo $\boldsymbol{C}$. botulinum são os mais potentes tóxicos de origem microbiológica conhecidos. Resistentes à ação proteolítica, elas são absorvidas pela mucosa intestinal e agem na placa neuromuscular, causando uma paralisia flácida (JASMIN, 1975).

Em aves, o botulismo foi descrito pela primeira vez nos Estados Unidos por DICKSON (1917). No Brasil, o primeiro caso foi confirmado em 1970 por BRADA et al., no Rio de Janeiro, em galinhas e patos. O período de incubação da doença varia desde algumas

\footnotetext{
ILaboratório de Anaeróbios e Doença das Aves, Escola de Veterinária, Universidade Federal de Minas Gerais (UFMG), Belo Horizonte, MG, Brasil. E-mail: flobato@vet.ufmg.br. *Autor para correspondência.

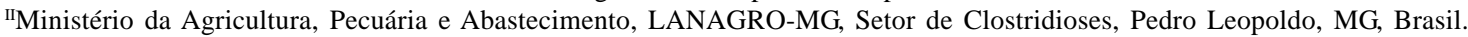


horas até dois dias após a ingestão da toxina. Dependendo da gravidade da intoxicação, as aves apresentam diferente quadro clínico, demonstrando instabilidade ao sr moverem e sonolência, e, nos casos mais graves, prostração profunda e paralisia flácida da musculatura das pernas, asas e do pescoço (HUMPHREYS, 1976). Os animais comumente são encontrados com as asas caídas, com o pescoço e cabeça sobre o chão, com as pálpebras semifechadas e plumagem arrepiada, sendo que as penas destacam-se facilmente. O psiquismo, porém, permanece inalterado (HAY et al., 1973; JASMIN, 1975).

Poucas alterações são observadas no exame post-mortem, podendo ser visualizada apenas uma congestão generalizada (BORLAND et al., 1977). O diagnóstico baseia-se nos sinais clínicos e na comprovação da presença da toxina botulínica. De acordo com SMITH (1980), a toxina se encontra em elevada concentração no sangue das aves, sendo assim possível usar o soro destes animais para determinar qual a toxina envolvida por meio da técnica de soroneutralização em camundongo.

No Brasil, são escassos os relatos da ocorrência de botulismo em aves. Portanto, este trabalho teve por objetivo descrever um caso de botulismo em ganso, ocorrido no município de Santa Luzia, Minas Gerais, Brasil.

O ganso examinado era oriundo de uma pequena propriedade da região metropolitana de Belo Horizonte, Minas Gerais. O animal foi encaminhado para o Laboratório de Doenças das Aves da Escola de Veterinária da UFMG para exame clínico. Foi constatado um quadro de paralisia dos membros e desprendimento das penas. Colheu-se sangue do animal em estado agônico e o soro obtido foi encaminhado ao Setor de Clostridioses do Laboratório Nacional Agropecuário de Minas Gerais (LANAGRO-Pedro Leopoldo). O animal foi necropsiado logo após o óbito.

A necropsia não revelou lesões significativas, o que, de acordo com SMITH et al. (1983), também é esperado no caso de botulismo.

A caracterização da toxina botulínica no soro do animal foi realizada mediante a técnica de soroneutralização em camundongos, conforme metodologia descrita por SEBALD e PETIT (1997). Todos os camundongos que receberam o soro suspeito morreram entre 6 e 8 horas após a inoculação, apresentando dispnéia e o aspecto característico conhecido como "cintura de vespa”, que ocorre devido ao aumento da flacidez dos músculos costais e abdominais (HAY et al., 1973). Os animais que receberam o soro aquecido a $80^{\circ} \mathrm{C}$ por dez minutos sobreviveram, enquanto que os inoculados com a mistura do soro com a antitoxina botulínica tipo D morreram. Já os que receberam a mistura do soro com a antitoxina botulínica tipo C sobreviveram, confirmando o diagnóstico de botulismo causado pelo Clostridium botulinum tipo C.

A confirmação do diagnóstico de botulismo pelo isolamento de $\boldsymbol{C}$. botulinum ou pela demonstração da toxina das culturas seria de baixa validade, uma vez que o esporo pode ser encontrado ocasionalmente no tubo digestivo de animais sadios. Já a demonstração da toxina no sangue e sua tipificação confirmam o diagnóstico (ROCKE et al., 1998).

Com base nos sinais clínicos e por meio da técnica de soroneutralização em camundongos, foi possível confirmar-se o diagnóstico de botulismo tipo C. Segundo a literatura, este parece ser o primeiro caso descrito de botulismo em ganso no Brasil.

\section{REFERÊNCIAS}

BORLAND, E.D. et al. Avian botulism and the high prevalence of Clostridium botulinum in the Norfolk Broads. Veterinary Record, v.100, p.106-109, 1977.

BRADA, W. et al. Botulismo em aves no estado do Rio de Janeiro. Pesquisa Agropecuária Brasileira, v.6, p.27-32, 1971.

DICKSON, E.C. Botulism: a case of limber-neck in chickens, Journal of American Veterinary Medical Association, v.50, p.612-613, 1917.

HAY, C. M. E. et al. Isolation of Clostridium botulinum type $\mathrm{C}$ from an outbreak of botulism in wild geese. Journal of South Africa Veterinary Association, v.44, p.53-56, 1973.

HUMPHREYS, P.N. Problems of keeping ornamental waterfowl. Journal of Small Animal Practice, v.17, p.607616, 1976.

JASMIN, A.M. Botulism. Veterinary Medicine of Small Animal Clinics, v.70, p.797-799, 1975.

ROCKE, T. E. et al. Preliminary evaluation of a simple in vitro test for the diagnosis of type $\mathrm{C}$ botulism in wild birds. Journal of Wildlife Diseases, v.34, p744-751, 1998.

SEBALD, M.; PETIT, J.C. Méthodes de laboratoire de bactéries anaérobies et leur identification. Paris: Institut Pasteur. Deuxième édition augmentée, 1997. 307p.

SMART, J.L.; ROBERTS, T.A. An outbreak of type C botulism in broiler chickens. Veterinary Record, v.100, p.378-380, 1977.

SMITH, G.R. Concentrations of toxin in the serum of waterfowl with botulism. Veterinary Record, v.107, p.513, 1980.

SMITH, G.R. Diagnosis of botulism in water birds. Veterinary Record, v.112, p.457-458, 1983.

TAKEDA, M. et al. Protective effect of botulism C/D mosaic toxoid against avian botulism. Journal of Veterinary Medicine Science, v.68, p.325-330, 2006.

WOBESER, G. Avian botulism - Another perspective. Journal of Wildlife Diseases, v.33, p151-156, 1997. 